\title{
A Mediterranean Lesson for Contemporary Architecture
}

\author{
By Giorgia De Pasquale
}

\begin{abstract}
Mediterranean landscape has been a great muse for artists of all ages. During the XX century, architects used the Sea - and the land lapped by the sea - as a reservoir of ancient knowledge, using the journey as a tool in a fluid experimentation laboratory in which new ideas about spaces, forms and sites were born. In this paper, I aim to discuss the XX century's Mediterranean lesson in Architecture, following the journeys of Gunnar Asplund, Le Corbusier, Josep Lluís Sert, Louis Kahn, Dimitris Pikionis, Giuseppe Pagano, and Alvar Aalto. Some topics emerge by comparing tracks, paths, attentions and sketches: the adherence of sections to the site, the determining influence of climate in the planning process, the geometric simplification of volumes, the relationship with light, the coincidence of forms of life and spatial structures. We can read these constants as an immaterial patrimony that, in the historical-geographical interpretation of Mediterranean «longue dureè» made by Braudel, tries to deconstruct the myth by decomposing it into architectural archetypes that come up to our days.
\end{abstract}

Keywords: Architecture, Mediterranean, Journeys, Drawings, Landscape.

\section{Introduction}

The Mediterranean area finds its unity in a rich iconographic variety, in a metaphysical place out of time (Braudel 1990). This kind of Mediterranean, a cultural and mythopoeic Mediterranean, was very used by people in the XX century to develop a new, free and modern architecture.

In this paper, I follow the history of this cultural process, analysing eleven journeys made by eight architects in the first half of 1900 century in the Mediterranean area. Notes, sketches, drawings and photographs have been gathered; tracks, paths, attentions and topics have been compared to find the archetypes from which a new Mediterranean culture was born.

\section{Volumes under Light}

Light is essential to all architectures but in the Mediterranean it becomes a key to discover the essence of forms.

"Méditerranée, reine des formes et de lumière. La lumière et l'espace. Le fait, c'est le contact pour moi en 1910 à Athénes. Lumiére décisive. Volume décisif: l'Acropole" (Le Corbusier 1965: 7).

Le Corbusier discovers the importance of light in the planning process during his Voyage d'Orient. On May 20th 1910 he leaves from Berlin and arrives in Istanbul on July 5th, passing through Dresden, Prague, Vienna, Vacz, Budapest,

*Research Fellow, Department of Architecture, Roma Tre University, Italy. 
Baja, Giorgavo, Belgrado, Jnajevaz, Naitscha, Bucarest, Tirnovo, Galvoro, Schipka, Kasanlic, Adrianopoli, Rodosto and Mount Athos. On the 7 September he lands in Daphne and then reaches Athens through the Aegean Sea. He is in Athens from the 14 to the 27 September and then goes to Itea, Delfi and Patrasso. He embarks towards Brindisi, from where he heads up the Italian peninsula travelling through Naples, Pompei, Rome, Tivoli, Florence and going back home via Lucerna. His sketches of the Voyage d'Orient continuously describe what the same architect will later call "the conscious, correct, and magnificent interplay of volumes assembled under light". Not "through" light, but "under" it. Matter expresses a passive role, while the inclination of every ray and its intensity determine the appearance of a space. A unity of landscape shows thanks to light, like the mass of the Parthenon, or the in-between spaces of the Caracalla roman thermal baths.

In the Mediterranean area, architects generate a utopian desire to relate buildings to the plastic way surfaces appear to react under light; while political, religious or ideological factors are overshadowed. It's a new revolutionary aesthetic value that fascinates architects that travel across the Mediterranean Sea, a new value based on ruthless, warm, strong light and precise, sharp shadows. The Mediterranean light shows itself with the intensity of an incision, like when it meets a musharabia, a celosia, or later on a brise-soleil; shadows draw lines and beat time.

In the sketches that Le Corbusier makes in Rome, at Caracalla (Figure 1), the relationship between light and shadows is sharp in the contraposition between dark and heavy masses, and light and fluid voids. The architect draws the masses of walls, heavy and oppressive; meanwhile a warm bright light, made with a yellow pencil, makes the space vibrant and beats the rhythm of the day. The drawing shows the shakiness of the void, which changes visions and proportions because of time, ray inclination and the fading of the contrasts between day light and shadows.

Figure 1. Le Corbusier, Caracalla, 1911

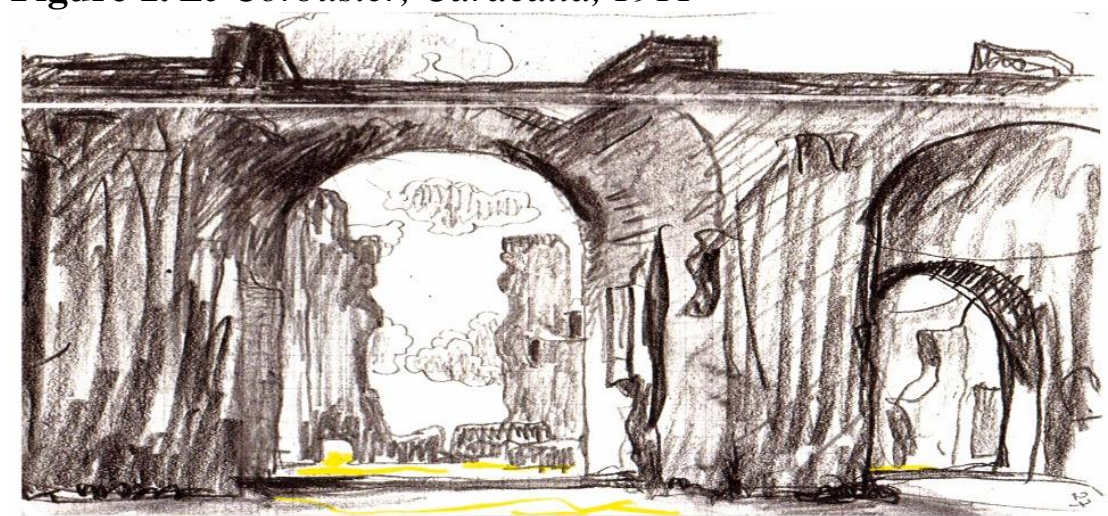

Source: Lotus International, 68, 1991. 
We can see the same attention to the topic of light in architecture in the travel notes and sketches made by Luis Kahn, 40 years after Le Corbusier Voyage d'Orient. In 1950, the architect stays at the American Academy in Rome, visiting many Italian cities like Siena, Florence, Pisa and Venice. In January 1951, Kahn heads to Cairo with a small group of residents at the Academy. From Cairo, they take the train to Aswan and from there the boat to Luxor, Karnak, Deir elbahari and Saqqara. At the beginning of February, they leave for Greece. Kahn stops in Athens. In front of the Parthenon he draws a view with crayons, describing it in its majesty and fullness: a mysterious winter light, a few clouds and the rest of the city just sketched. The sketch underlines the relationship between light and wall mass. Together he writes: "when we think of great buildings of the past that had no precedent, we always refer to the Parthenon. We say that it is a building that grew out of the wall with opening. We can say that in the Parthenon light is the space between the columns (a rhythm of light, no-light, light, no-light) which tells the tremendous story of light in architecture that came from the opening in a wall" (Kahn 1951: 484).

In these Mediterranean journeys, the space becomes more and more absence of material. In this system, taking out material means giving shape to the box, and defining the evolution that light will follow. This discovery defines a planning method: space comes from the subtraction of matter. A horizontal subtraction of material links the inner space of a building to the landscape; a vertical subtraction defines the exclusive relation of the patio that connects the inner space to the sky, and cuts out the surrounding landscape. Each subtraction seems to give a proper answer to a precise task and an innovative appearance to volumes. So, in the planning process, different height openings-in-the-wall substitute the classic window. Architecture becomes a play of "mirabili soluzioni in termini di pieni e di vuoti" (Pollini 1933: 35). The Austrian architect Bernard Rudofky journeys to Greece, Turkey and Italy between 1924 and 1934 and stops to live in Capri for two years (1932-1934). In 1935 he writes that windows are "miserables" and "bourgeois" and he analyses the differences between Nordic and southern ones: "nei paesi meridionali le finestre sono poste all'altezza dei sedili, queste sono ancora le più simpatiche (vi sono sedute delle donne con occhi ardenti). Nelle regioni più nordiche la finestra incomincia dalla mezza persona in su. Lassù è la preferita di uomini sazi che tentano di riempire l'apertura con la testa appoggiata" (Rudofsky 1938).

A consequence of this way of thinking about light and volumes is a reflection on the power of indirect and broken light, as we can see in the sketches of the Canopy (Figure 2) Le Corbusier makes in Villa Adriana. This fascination is clear in his following projects: La Tourrete, Notre Dame du Haut chapel in Ronchamp, Villa La Roche, etc.

An interpretation of the different use of holes can also be seen in another Mediterranean traveller: Adolf Loos' Venetian project for Villa Moissi. Here the architect does not use a regular and symmetrical composition of the facades, but he measures the openings based on the sun: regular windows towards west, balconies and terraces to the east. The south wall is totally blank; to the north small openings guarantee ventilation, thanks to the difference of temperature between 
the two opposite façades. Natural light reaches every room, even if through informal ways, like the small openings on the western facade or the terrace skylight. In its three dimensional modelling, the volume seems to be crossed with light, as if it were a fluid element able to reach even the most remote part of the house.

Figure 2. Le Corbusier, Villa Adriana, 1911

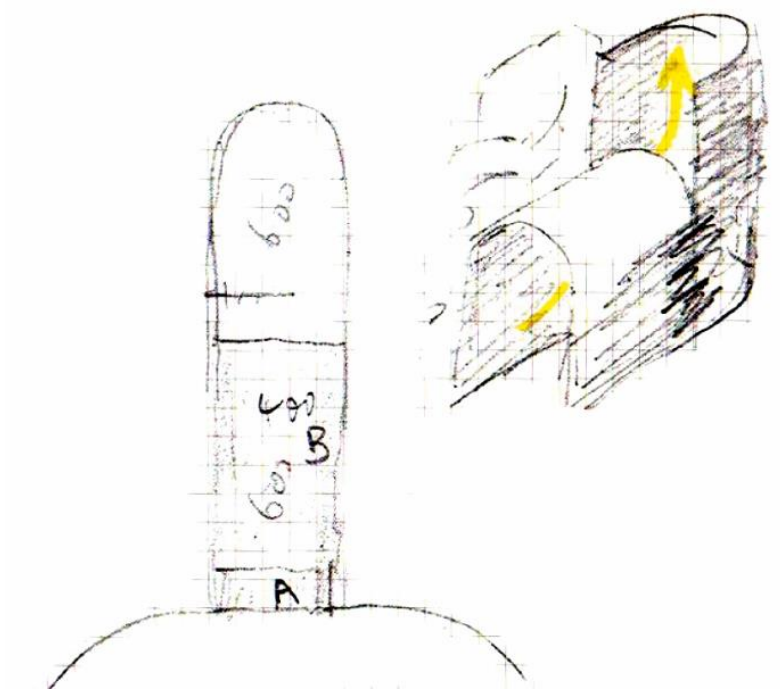

Source: Lotus International, 68, 1991.

Figure 3. Lluis Sert. Casa en el Paseo de la Muralla, Ibiza, 1961

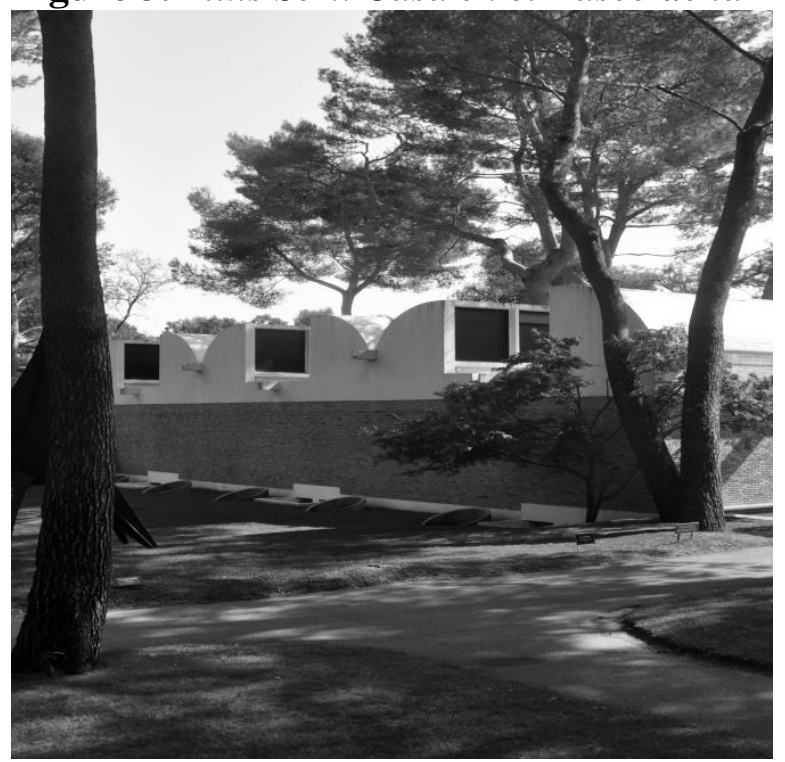

Source: Capitel A., José Luis Sert, Universitad De Valladolid, 2002.

Slight variations of intensity measure the inner spaces. Ibiza dwellings, Mirò Museum and the Maeght Foundation by Lluis Sert (Figure 3), La Tourette by Le Corbusier (Figure 4) or Casa Gilardì by Luis Barragan (Figure 5), have the same natural light coming unexpectedly from above, to generate a metaphysical space. It 
is an inclusive and introvert architecture, which eliminates any possibility of orientation and shows the rhythm of day, where light is a protagonist.

Using the light as a plastic material, architecture becomes a transitional space: from light to shadow, from light to dark, from white to black or, with the words of Spiros Papoalukàs, from light, to dark and "half-light".

Figure 4. Le Corbusier. Convent of La Tourette, 1957

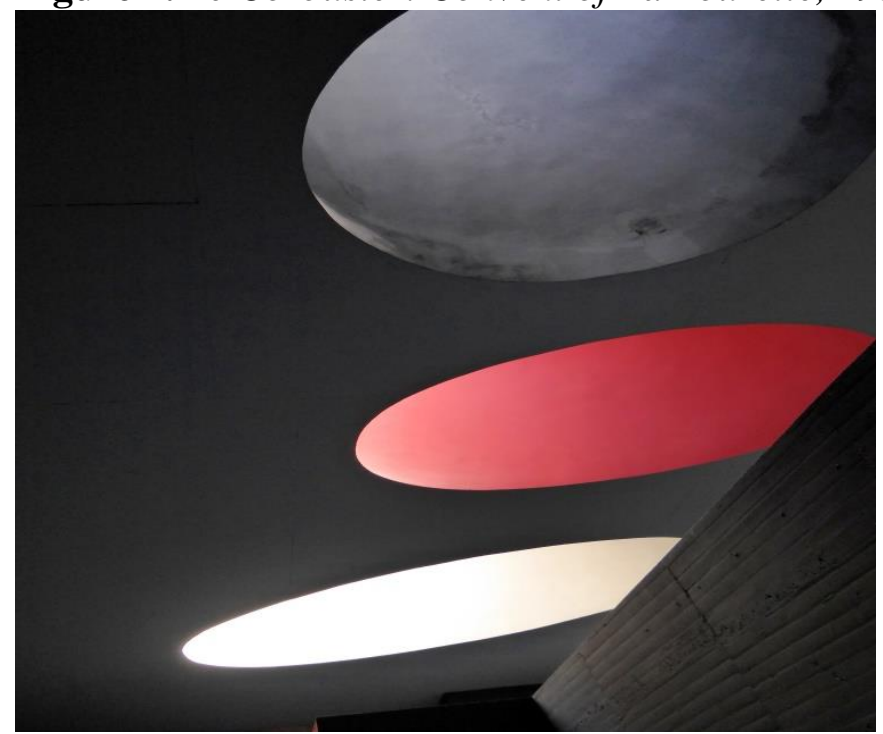

Source: Photo by V. Palmieri.

Figure 5. Luis Barragan. Gilardì House, 1975

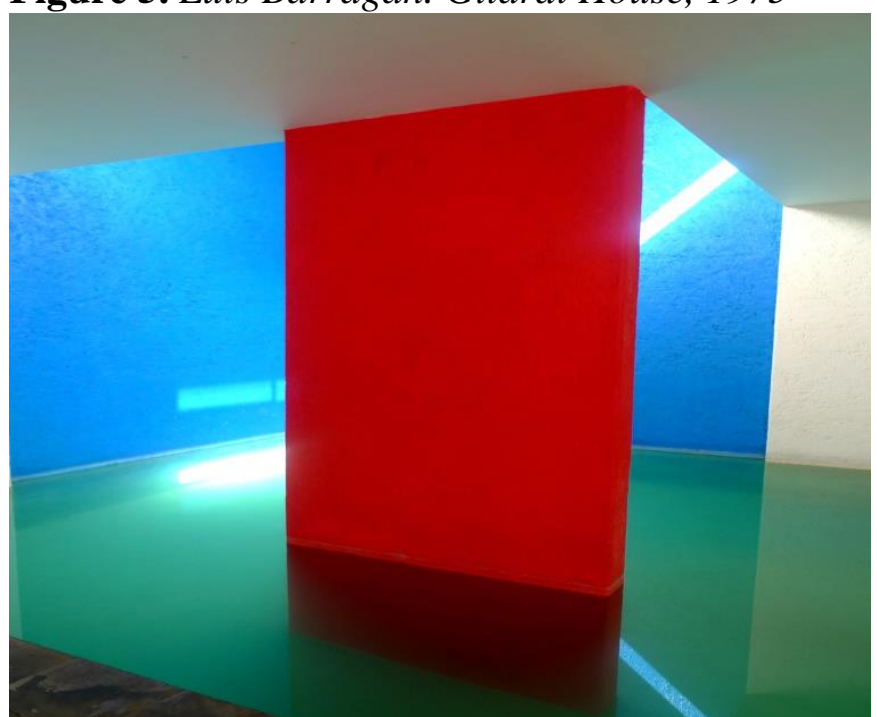

Source: Martinez A. R., 1902-1988 Luis Barragan, Electa, 1996.

\section{Deep-Rooted Architecture}

In the Mediterranean, mountains arrive to the sea. As Fernand Braudel explains, these are young mountains, tall and moved: Alps, Apennines, Balkans, Tauro, Lebanon, Atlas, Pyrenean. Geology, together with a long history of suffered 
drainages, and a slow organization of fair areas always threatened by malaria, explains the paradox that near the Mediterranean area the history of mankind began on mountains and hills. This characteristic influences architecture. Cities are built up on cliffs, laid on rocks, far away from epidemics and incursions. This feature in the geological and historical data affects above all the architects who come from Northern Europe.

In November 1913, Gunnar Asplund (Stockholm, 1885-1940) leaves toward Italy and Tunis. He stops in Rome for nearly a month and then goes to Naples. Along his way, he writes in his notebook: "The road from Rome to Naples is incredibly lovely as it makes its way through the mountains. Vineyards and vineyards and little towns huddled high up the slopes, their roofs and walls and church towers forming the very crests, a rich and peaceful line" (Gunnar 1915).

In 1924, the Finnish architect Alvar Aalto (Kuortane, 1898 - Helsinki, 1976) travels to Italy for the first time and he is impressed by the relationship between anthropological space and morphological characters in the landscape. The architect is charmed by the hard ruthless orography: Alps, more that columns, architraves, cornices and universal canons, are the first to be represented in his notebook during his journey. The real interest is a sudden dialogue between artificial forms, together with nature's organic shapes and the sense of orientation they spread. Urban structures follow the impossible form of the land by refusing a horizontal development. They adapt themselves to topography, and the form of the territory acquires a new result thanks to human action, in a sort of cultural symbiosis (Weston 1995: 102). In 1926 Aalto writes: "The town on the hill... is the purest, most individual and most natural form in urban design. Above all, it has a natural beauty in that it reaches full stature when seen from the level of the human eye, that is, from ground level' (Aalto 1926: 13). Many sketches reveal the interest for this particular landscape whose primary structure is given by the shape of the land, rather than by buildings (Figure 6). The terraced cultivations have the same importance of classical Greek ruins. The architecture capable of modelling the territory, at the same time being modelled by it, is a fascination that we find in his planning experiences which would follow later on: in the Iranian Museum of Modern Art (1970) where the building placed on top of a hill abandons its formal identity to enhance that of the existing hill; in the Muurame Church project the architect forgets the evident geographical facts (a flat area) to propose again the harmonious conditions he saw in Italy, "a sleek campanile, more than twice the height of the nave, complemented the eroic arch, which itself recalls Leone Battista Alberti's Sant'Andrea in Mantua" (Reed and Frampton 1998). 
Figure 6. Alvar Aalto, Italian Trip Sketches, 1924-1948
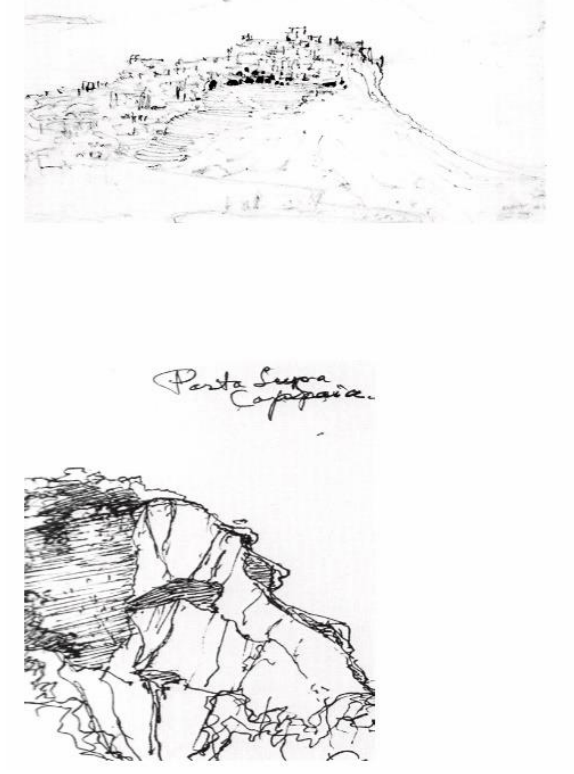

Source: Lotus International, 68, 1991.

Travelling across the Mediterranean is an occasion to investigate the relationship between human and nature, architecture and landscape. Architecture on the top of a sloped hill can represent also a human predominance towards nature, causing unease and pride.

When in Greece, during his training journey, on 7 September 1910, Le Corbusier lands in Daphne, going on a mule to Karie's and getting to the convent of Agiou Pavlou Xeropotamou. There he writes: "From the window lodged at the end of a deep splay, three times, 1 watch at dawn the light invade this endless space, while below, at the foot of the walls, the olive trees looked like tiny lichen. How painful is this inability to record on paper the impression that the patches of earth, the perpendicularity of the red rocks, the expanse of the sea have stirred in the depths of my soul, without opening to them the light of day!" (Le Corbusier 1911: 185). (Figure 7).

Figure 7. Le Corbusier. Monte Athos, Simonos Petra Monastery, 1911

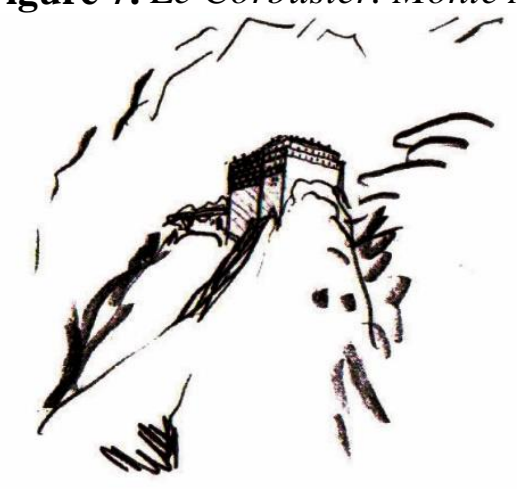

Source: Lotus International, 68, 1991. 
The same lecorbusieran dream appears in the planning process of Luigi Cosenza and Bernard Rudofsky in 1937 . They propose a single family house with 22 rooms on a narrow plot 500 meters long in Naples. Villa Oro terraces work as a boat bridge dominating the waves from a 40 meter height; the building is arranged on many levels and is surrounded by a rail explicitly inspired by boats. The metric choice reinforces the abstract image of pure volumes through white plaster, in contrast with the stone podium (Figure 8). In this project the topological research prevails on type affirmations. The volumes succession, made of joints between void and masses, draws a free plan. The view towards the bay undergoes a sort of multiplication. Unexpectedly, an architecture able to keep together the rationalist rules and a potential of freedom, with respect to rationalist rigour, takes form in a remote corner of Europe, after the travel reflections about ground, light and spontaneous life. The aggressive geographical connotation and the pleasantness of the Mediterranean climate drive the attention of planning towards the creation of open air spaces, capable of breaking up the pure volume geometry, and shaping it as if it were a handmade organism. On that Mediterranean coast a naturalistic version of Existenzminimum develops, as an attempt at using every single space, either open or closed, in every level and direction. Different functions find their place in elementary minimal volumes hosting magnolias and figs, sustained by local calcareous stone. The sequence of rooms and the service path embrace various levels and seem a very mediterranean promenade architecturale. The extreme character of the context and the many limitations coming from the difficulties met during construction become the occasion to realize a rational architecture, new and functional.

Figure 8. Luigi Cosenza, Bernard Rudofsky. Villa Oro, Posillipo, 1937

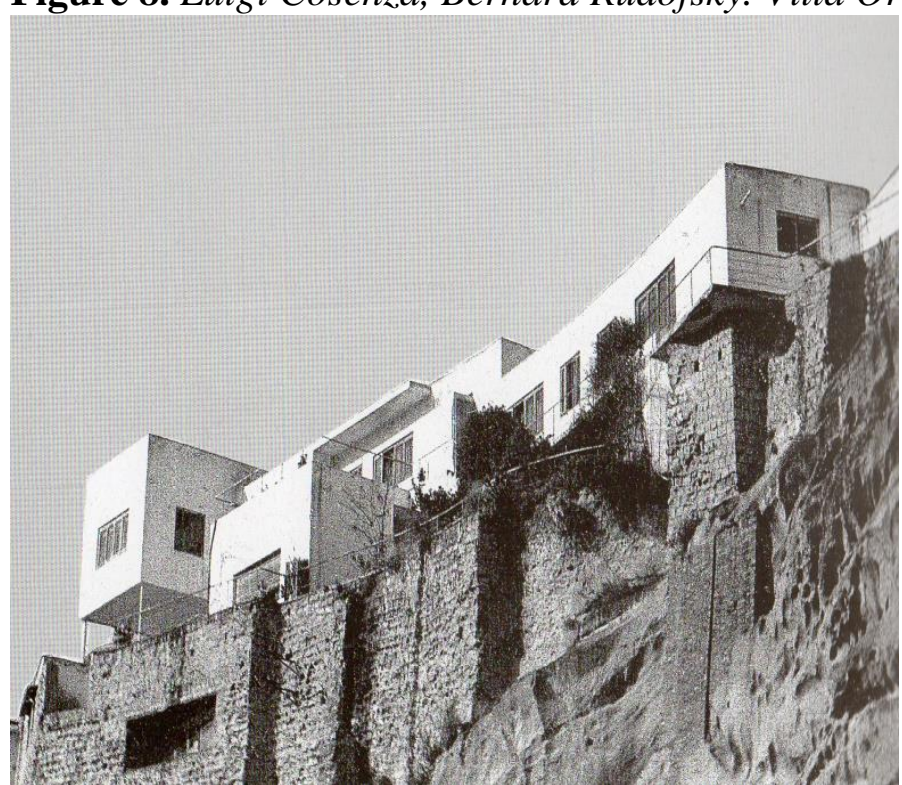

Source: Buccaro A., Mainini G., Luigi Cosenza Oggi 1905-2005, Clean Edizioni, 2006.

The relationship between soil and building in the Mediterranean continuously shows, from either an orographic or an established point of view, in the mixture of 
natural and artificial elements, as well as in the denial of this intimacy that at the same time legitimates it. Human works and landscape merge, as in Kahn's drawings, made in Greece (Figure 9): it is difficult to distinguish in the drawing what is natural and what is man-made, while the contrast between masses and voids, light and colours, is very clear.

Figure 9. Louis Kahn. Delphi, 1951
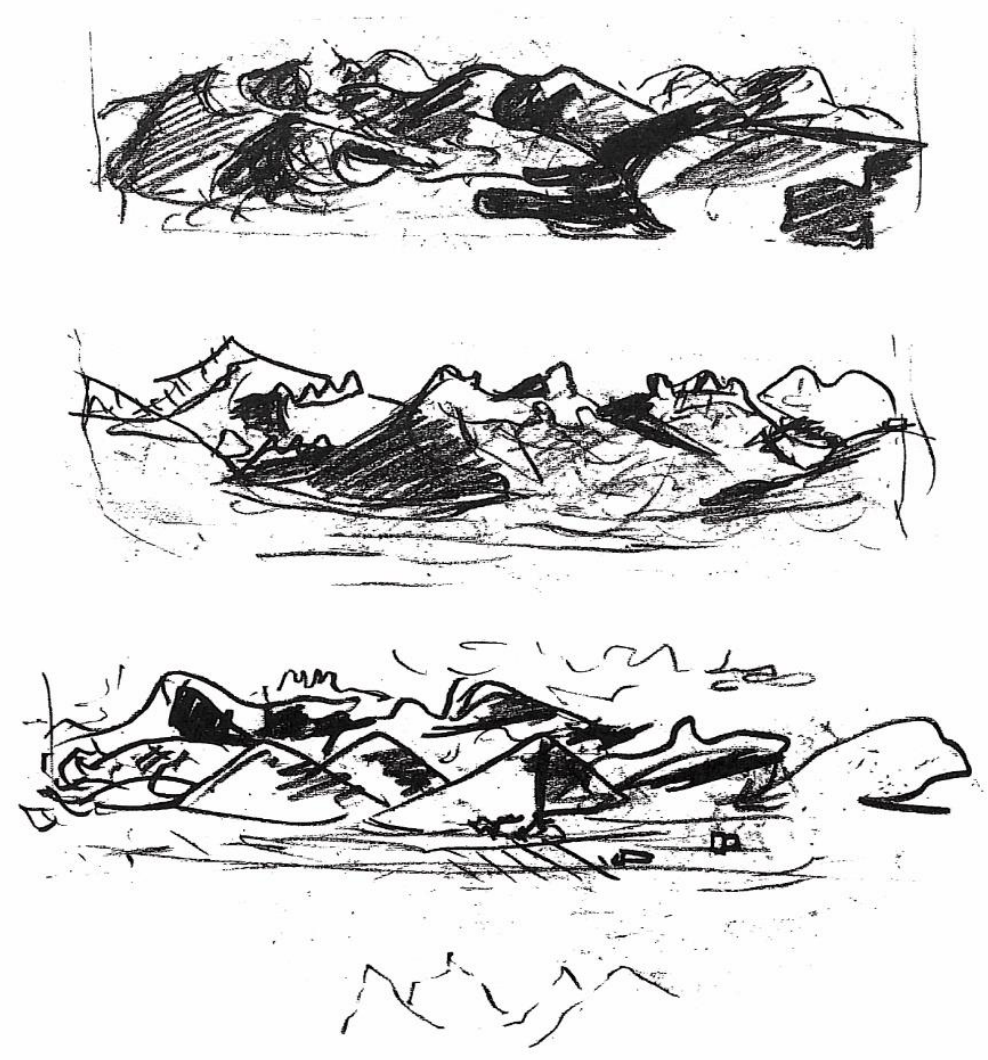

Source: Feldman E., Wurman R.S., The Notebooks And Drawings Of Louis I. Khan, The Falcon Press, Philadelphia, 1962.

\section{Space Sequences and Axiality}

The study of spontaneous architecture during Mediterranean journeys unhinges every a-priori compositional intention. Karl Friedrich Schinkel for example, after his tour between 1820 and 1830, opposes the rigid, static and axial way of planning in the text Das Architektonische Lehrbuch, dealing with tectonic and compositional rules. In the text Schinkel says there is a sort of hidden order, not very well investigated at the time, referring to the asymmetries popular architecture showed. "The order - he writes - has to be linked to the inner space function, and can be reached through the use of symmetry, that anyone can 
understand, otherwise through less evident means, that only the ones aware of primary principle can understand"1.

Geometry and harmony become elusive when they appear in minor architecture, but in modern architects the expression of that apparently ill-formed composition becomes a subject of attention. Le Corbusier suffers the same fascination in Costantinopoli, on the 19 August 1911:

"Wouldn't it take me a lifetime of labour to harness these simple and eternal forces, fraught with the uncertainty of ever attaining the proportions, unity, and clarity worthy of even a little country cottage built in accordance with the invaluable laws of an age -old tradition?" (Le Corbusier 1911: 177).

On this subject, the work of Omada Filòn is very important. This group of Greek artists, which included painters, poets, sculptors, journalists and architects, travel in 1925-1926 around some islands nearby Athens. Aegina Island among them plays a fundamental role, as this is the place where Omada members go around with students to create a great database by taking sketches, documents and objects. They investigate every form of popular art: houses, stairs, terraces, decorations and furniture. The aim is to read Greek landscape and architecture like a privileged place for any sort of artistic inspiration. The group seems very interested in the series of cubic volumes composed in one building, all linked by two crucial factors: life and sensitivity. They study above all a small house on Aegina Island, built without rules by the owner, a peasant named Rhodakis. According to Dimitris Pikionis (Piraeus 1887 - Athens 1968) the L shaped house could be an answer to the modernist «machine a habiter» (Ferro 2004). Rodakis House is composed of a main building, with big rooms for many uses, that is to say living or keeping animals. The only separate volume is the kitchen, placed inside the court. The Omada Filon's description of the house seems to be the easiest way to tell what a Greek 'landscape' is: past experiences, but also needs, traditions and religion. The interpretation of the threshold defines the creative process connecting the building to nature; its limits are not well defined. The threshold can't be clearly identified as it develops along the path between the fence and the entrance to the house.

The house plan lets us approach the building thanks to a series of progressive movements, by taking the visitor among more and more compressed spaces, in a spontaneous but clear rhythm. This entire path is in the open air, developed between the white and tall fence and the independent volumes of the building; it takes from the public entrance to the inner intimate patio, overlooked by the whole of function. This is the place where life develops. In this small Aegina house, we can recognize the anticipation of an architecture that is understood by being walked in and that, in the process, succeeds in giving the visitor an endless number of perspectives.

On the other side of the Mediterranean basin, in Spain, another group of artists called GATEPAC is founded in 1928 and from 1931 it promotes a survey

\footnotetext{
${ }^{1}$ The book was never published, it is cited in J. Francois Lejeune, M. Sabatino, Modern Architecture and the Mediterranean, Routledge, Oxon, 2010, page XVII.
} 
campaign in order to underline formal traditions of popular Spanish architecture. The Catalan architect Luis Sert (Barcelona, 1902 - 1983), one of the co-founders of GATEPAC, after many journeys writes:

"Ni el alzado, ni la planta responden nunca, en la arquitectura popular, a una composiciòn premeditada. El conjunto no es otra cosa que una sencilla justaposiciòn de cuerpos simples con el mayor sentido racional. Primero, es un pequeño añadido con uno o dos dormitorios màs, luego, un porche, después, un establo que hay que ampliar, etc... (...) Y es curioso observar como estas construcciones han servido de modelo a una arquitectura académico popular, artificiosa, que ha encontrado en las manifestaciones populares una fuente de inspiración de donde sacar sus inagotables formas. Faltos de una base moral - puesto que en arquitectura deberia existir una base moral - estos arquitectos han partido del aspecto pintoresco de las construcciones rurales, destruyendo incoscientemente los principios básicos en que estás se apoyan" (Lluis Sert, 1935).

Starting from the Mediterranean, in these years, the attention of architects is directed towards the comprehension of a wisdom in the planning process that architects believe they are about to forget. When in front of the Acropolis, Eric Mendelsohn (Allenstein, 1887 - San Francisco, 1953) is not shocked by the architectural bigness or by proportions, "he was especially impressed by the way in which the approach is so calculated and integrated with the entire complex". Architects are looking in the ancient heritage for new rules to do architecture. Some years later the Acropolis fascination will come back in Weizmann House (1950), where Mendelsohn breaks the symmetry of the court scheme by introducing dynamic data into the composition. In Mendelsohn's project, to get to the main entrance, you need to discover every single side, and consider the plastic feature of the house while entering the inner space.

The dynamic development of the composition based on the more or less regular succession of different points of view, becomes a leitmotive to those who travelled to the banks of myth. It's a new compositional grammar that comes from the observation of the Mediterranean vernacular architecture.

"Le Corbusier had devoted exceptional attention to Pompeii in his travels: he annotated his Baedeker, kept a list of houses he had examined, and ornate numerous sketches and watercolours on the site. Moreover, he must have been familiar with the reconstructions of Roman atrium-houses as they appeared in the widely published book by August Mau. (...) The facade-like treatment of interior elevations, the open stairs ascending to internal balconies, and the gathering of adjoining spaces around an open core were not totally new to architecture. But the Roman houses Le Corbusier examined in Pompeii combined familiar elements in a decidedly uncommon manner. The axial deployment of the atrium-house afforded a "promenade» from the street to the rear garden across hallways and atria. The sequence of highly differentiated cubicles and the subtle shifts in their alignment are especially remarkable in the Pompeian House of the Tragic Poet. The judicious displacement of emphasis from the central axis recalls immediately the shift of Le

${ }^{2}$ S. King, Interview with Mrs. Mendelsohn, quoted in J. Francois Lejeune, M. Sabatino, Modern Architecture and the Mediterranean, p. 188. 
Corbusier's little balcony from its originally central position on the La Roche gallery to the extreme left side, as well as the counterbalance between the extrusion of the living room bay in the Jeanneret house and the recessed hall-bay of the La Roche house. The centric entrance to the atrium of the Pompeian house and the lateral displacement of the right-hand walls in front and back of the atrium-corridor imply a comparable relation to the guiding axis of the house in Auteuil" (Forster 1979).

In Villa La Roche (1923) the entrance is placed in a key position, and takes guests from one floor to the other through stairs, as an atrium made of many floors (Figure 10). Canonical axes are not recognizable anymore, and the main space gives a sort of dismay. The Pompei Forum plan, with its many hierarchical axes, provokes a sort of joy of the spirit, even if it would be refused by the Ecole des Beaux-Art. Le Corbusier deduces in his Towards an architecture: "the axis is not dry theory", it ties together the principal volumes which are nearly inscribed and differentiated one from the other; we don't have to put all the architecture on axis, the result would be similar to that of many people speaking all at once. Order withdraws from symmetry, looking for the axis hierarchy, which will later become a hierarchy of aims and a classification of intentions.

\title{
The Economy of Expressive Means
}

Mediterranean traveler architects refused at the same time any sort of historicism, together with the use of predefined styles and eclecticism. Their revolution is made of an out-of-time attitude towards monuments: the historic building is looked at in its most essential form, the square as a sublime synthesis of space and functions. All architects put into practice many forms of abstraction. Every object unchanged over centuries becomes different, as if seen under a different point of view: dovecot towers become vertical episodes on persisting horizontal dynamics, loggias become pure subtractions, external stairs an addition to the original volume. In 1929 the Italian architect Plinio Marconi (Verona, 1893 - Roma, 1974), after many trips to the Italian Tyrrhenian small islands underlines this sort of primitiveness arising in the new architectural sensitivity.

\begin{abstract}
"Lo studio e l'attenta considerazione di queste fabbriche elementari -si riferisce alle architetture minime del mediterraneo- ci giovano invece sotto altri punti di vista più larghi. In primo luogo possiamo assorbire da esse, rimanendo nel nostro piano di uomini attuali, quel senso di aderenza alla costruzione che le ispira nel loro: essere nell'ambito dei nostri mezzi così costruttivi e semplici come il contadino di Capri lo è stato coi propri. Impariamo ancora che, specie nelle piccole architetture, quando il senso del volume, delle superfici e dei profili è nettamente formulato e artisticamente potenziato, quando il colore degli impasti è ben scelto, non è necessario aggiungere membrature non esistenti per fare una cosa bella: ciò è importante ai fini delle tendenze moderne" (Marconi 1929).
\end{abstract}

In Italy, the article by Marconi came out with many other on similar topics, dealing with spontaneous construction in the Mediterranean area: P. Egidi (Appunti su alcune costruzioni di Siria e Palestina) 1921, E. Cerio (L'architettura 
minima nella contrada delle sirene) 1922, A. Maiuri (Architettura paesana a Rodi-La casa di Lindo) 1924, G. Capponi (Motivi di architettura ischiana) 1927, R. Pane (Tipi di architettura rustica in Napoli e Campi Flegrei) 1928.

In Lesson from Rome (1928) Le Corbusier describes the buildings he had seen during his journey, considering the pure volumes as the very starting point.

"The light caresses the pure forms: it renders. The simple volumes unfold vast surfaces that express themselves with a characteristic variety depending on their being domes, barrel vaults, cylinders, rectangular prisms, or pyramids. The surface decoration (openings) is of the same geometric class. The Pantheon, the Colosseum, the aqueducts, the Pyramid of Cestius, triumphal arches, the Basilica of Costantine, the Bath of Caracalla. No verbosity; ordonnance, a single idea, boldness and unity of construction, the use of elementary forms. Sound morality. Let us retain from the Romans the bricks and Roman cement and travertine stone, and let's sell roman marble to the millionaires" (Le Corbusier 1928: 200).

As Omada Filon in Greece and the GATEPAC in Spain, the architect Giuseppe Pagano travels Italy to document the vernacular tradition in architecture. He takes photos and planimetric sketches of the main typologies of rural building, underlining the tectonic and material simplicity of the vernacular in opposition to its picturesque simulation. For him, this constituted a potentially new impetus in the modernist, rationalist design that could lay claim to the traditional values grounded in Italy's agrarian past, and ultimately cast it as a source for contemporary functionalist practice (Sabatino 2008: 350).

"Questi elementi, adesso propri del movimento moderno provengono dalla nostra cultura mediterranea e si sono conservati in tutti i tempi. Il movimento moderno li ha riscoperti. Questa architettura limpida è il linguaggio autoctono della civiltà mediterranea, linguaggio che parla innanzitutto con spregiudicato raziocinio e che, dallo stesso ragionamento funzionale trae motivo di lirica espressione artistica. Questa maniera di esprimersi è assai prossima, moralmente e quasi anche formalmente, al credo degli architetti contemporanei. (...) questa orgogliosa modestia tanto analoga al sentimento dell'architettura contemporanea e per far ricordare quanto sia necessaria la coerenza con il tempo, col clima, con la tecnica e con la vita economica per fare onesto lavoro architettonico" (Pagano 1935).

Vernacular architecture examples, that had received romantic attention in the past century, become masters of building sincerity. The essentiality of a building, born spontaneously and with minimal resources, becomes the aim of modern times.

"Da queste architetture mediterranee anonime, da queste architetture naturali, nate d'istinto, come le agavi giganti e i fichi d'india che le circondano, discende per noi una lezione, ancora oggi valida. Per noi, anonimi costruttori individualisti, figli del progresso meccanico, della tecnica e della cultura, che sapendo tante, troppe cose, ne abbiamo dimenticate tante altre. Lezione di morale e di logica (semplicità, sincerità, modestia, umiltà, aderenza alle necessità, rinuncia al superfluo, adeguamento alla scala umana, adattamento alle determinanti locali e ambientali), lezione di vita (vasto impiego di elementi "intermediari" tra il vivere al chiuso e il 
vivere all'aperto: loggie, terrazzi, portici, pergole, patii, orti murati, ecc..), lezione di stile (antidecorativismo, amore delle pareti liscie e delle soluzioni plastiche elementari, collocazione e inquadramento dell'edificio nel paesaggio)" (Figini 1950).

The adherence to needs, together with the discarding of the superfluous and the attention to human scale, become a key to read contemporary reality. It is a Mediterranean thought. Mediterranean architecture is seen as made of masses and rationality; it is mainly based on two elementary operations: addition and subtraction. The main feature thought is that material modelling very often comes from functional needs: loggias, terraces, porticoes, patios, enclosed orchards. Stairs are elements to pass by, to be built outside the building. Stairs and loggias are taken out from the main building then, and porticos and pergolas are added, never leaving the original form to itself.

\section{The Outdoor Room}

One of the most studied themes by architects in the Mediterranean is the mystery inside the enclosed walls, so well expressed in the introvert character of buildings. Life developing in the outdoor domestic spaces charms Le Corbusier during his Voyage d'Orient: the enclosures break the relationships with the public realm, only to reveal its heart and liveliness once the surprised ranger trespasses.

"In Bursa, in Asia Minor, at the Green Mosque, you enter through a small doorway to human scale; a very small vestibule works on you the change of scale that's necessary to appreciate, after the dimensions of the street and the place you've just come from, the dimensions that are meant to impress you" (Le Corbusier 1928).

During the architects' trips, the patio is rediscovered not only as an element capable of generating a specific climate in its interior, but also as a new, smaller world where human scale lets anyone sit down and enjoy the fresh air during summer time.

What really charms architects, above all Le Corbusier, is the form of discretion typical of the Mediterranean area: urban enclosures, traditional musharabie, women veils.

Now it seems to me they (the girls in Istambul) are ravishing despite and also because of that second skirt flung over their heads that makes an impenetrable veil. You will find real coquettes underneath. I bet you, you old bony fakir (Klip), that almost all of them are young, adorable, with ivory cheeks a little full and with the innocent eyes of gazelles - delicious! After all, these veils conceal a penetrable mystery. It seems to me that there are thousands of them who wish to display their beauty, and devilish as they are, they know how to get around all the codes. They have a touch of genius... (Le Corbusier 1911).

After twenty years, Le Corbusier is again travelling toward the south Mediterranean area. In 1931 he goes to Spain, Morocco and Algeria. When back 
from Algeria, Le Corbusier describes the impressive contrast between M'Zab city centre's architectural bigness and the simple flow of its daily life in patios. The most striking element to him was the strong, apparently impenetrable external walls. They define a system of properly lighted and well working inner spaces.

"The houses are completely closed off from the alleys. But, inside, opening onto the abundance of fertile stands of trees, is completely equipped, perfect, efficient, eminently functional, on a human scale" (Le Corbusier 1931).

In 1952, the Mexican architect Luis Barragan (Guadalajara, 1902- Mexico City, 1988) was also very influenced by the observation of local southern Mediterranean traditions.

"Un viaje que hice al África ha sido el que más me ha impresionado en mi vida; ví las construcciones que se llaman casbah, en el norte del desierto del Sahara. Eso es lo que encontré plásticamente más ligato al paisaje, más ligado a la gente que lo vive, a su ropa, al ambiente, inclusive más ligado a sus propias danzas, a su familia; ahí encontré la integración perfecta de la religión con todo el ambiente en que se vive con las cosas físicas que se tocan" (Barragán 1984).

The central space surrounded by thick walls and opened on top, seems to be very important for the development of the sort of life that charmed travellers. Patio becomes a symbol of "joy”. Once back to México Barragán deals with the topic of housing and, thanks to his travel experience, the architect opposes Guadalajara (his native city) model of growth based on chalets, single family dwellings. The patio acquires a symbolic value, as it becomes the symbol of family unity: the «sense of family» and Mediterraneism become the fundamental mean to get his clients' favour, to conjugate their traditions and their intercontinental desires. In the house he planned for his friend Efrain Gonzalez Luna in 1929, for example, privacy is underlined by using filters such as pergolas, fences and jalousies. The in-out relationship is always exclusive: a long corridor reaches the hearth of the house, the living room has tall windows which let the light in but don't allow people to look out, to underline its intimate and domestic character.

Patio becomes a model to be exported. During his stay at Harvard University, Lluis Sert will also work a lot on it:

"Patio, intriguing word, readily conjures visions in one's mind of sunny skies, blue water, palm trees and balmy breezes. For surely the association between these climatic and geographic qualities and the walled residential yard is inevitable to the average American observer; particularly if he is experienced in any way with the admirable architectural traditions of the Mediterranean area. To the more engrossed observer there is less a geographic limitation since the patio is frequently found in Central and Eastern Asia, Africa, Central and South America and (I am sure) elsewhere. The Mediterranean connotation, however, may be rather formly established in the Western mind' (Sert, c. 1950).

The Patio becomes an «outdoor» room, where all domestic functions can be held. To this extent, in the second half of the 20th century, the patio model 
gains popularity as it represents one of the most valid answers to the architects' interest towards flexibility. The open space can host different functions along the day. The activities change depending on a door left open, or on the possibility of expanding to a room of the house. Open air life, enclosed on its four edges, becomes a universal inspiration; it is confirmed, again, by Le Corbusier project of elevation of Beistegui's flat in Paris. In this case the terrace will be unmercifully surrounded by white walls, ignoring the wonderful view towards Tour Eiffel, leaving only the top part visible.

The outdoor-room is used in very different ways by traveller architects: the big space for the audience of Skandia theatre by Asplund, for example, is opened towards the blue sky, inspired by the one he had experienced in 1913 in Tunis: "Above our heads a sky clear and deep the like of which I have never seen, such a tone in the colour that I constantly imagining the sky as a vast blue-painted dome. All the buildings white, the streets a dazzling chalky white, making the eyes ache and feel like narrow slits" (Gunnar 1913).

\section{Sitting in the Sun as Long as it is willing to shine}

Thanks to the many journeys, in the first part of the XX century a Mediterranean modus vivendi begins to spread in the entire world.

After having lived two years in Capri, Bernard Rudofsky (Suchdol nad Odrou, 1905 - New York, 1988) suggests, in an article published on Domus in 1938, to go back to the Mediterranean "sapienti usanze senza tempo", that modern culture seems to have forgotten: "il sentirsi vellicare la pianta dei piedi dalla sabbia, da erba ben rasata, da un marmo levigator" (Rudofsky 1938). According to Rudofsky, we need to abolish the act of "lavarsi, barbaramente ridottosi ad una piccola vasca di acqua stantia, ritornare ad avere una stanza dedicata all'uopo", where a lower floor can host water and where the sun can go in during the day. " $E$ la seduta... ritorni ad essere un cline".

Goethe had already told in his Viaggio in Italia (1787) about the sensual and slow rhythm of life of Mediterranean people.

By the time we reached the outskirts of Naples the sky was completely cloudless, and now we are really in another country. The houses with their flat roofs indicate another climate, though I dare say they are not so comfortable inside. Everybody is out in the streets and sitting in the sun as long as it is willing to shine. The Neapolitan firmly believes that he lives in Paradise and takes a very dismal view of northern countries. Sempre neve, case di legno. gran ignoranza, ma denari assai - that is how he pictures our lives. For the edification of all northerners, this means: 'Snow all the year round, wooden houses, great ignorance, but lots of money.' Naples proclaims herself from the first as gay, free and alive. A numberless host is running hither and thither in all directions, the King is away hunting, the Queen is pregnant and all is right with the world" (Goethe 1786-1788: 184).

More than a century later, the German architect Mendelsohn will be a victim of the same fascination in Corsica: "The Mediterranean contemplates and creates; the North winds itself up and labours. The Mediterranean lives; the North defends 
itself. [...]Here one can grow old without work...No comforts, just sun, no desires, just being" (Mendelsohn 1931).

According to the traveller architects, the way in which Mediterranean people live has a consequence in their cities' development. The poetry of the Mediterranean lifestyle becomes a reflection on all open spaces: light, the harmony of the orographic relationship with nature, the concatenation of spaces, visual sequences. Architects steadily look at the use of the public realm, of roads and squares. In the Mediterranean area, each city-system has its own centre, or its medina, whose form comes from the tangle of paths, from the buildings knotting, from past and present merging. Moreover, climate and public space compression helps their use all day long. Architects are fascinated by a public realm, intended as a natural prosecution of domestic space, where one can bring chairs and furniture during summer evenings. They represent the Mediterranean modus vivendi in a succession of sketches and photographs portraying men, women, children and animals that live the most unusual street corners. In Naples Gunnar Asplund writes: "The streets of Naples filled with urchins, so that one can hardly get along, confetti throwing and gay life. In the evening from the boat in the harbour, with the reddish lights reflected in the deep blue of the sea and the moon shining for all it is worth, we threw coins on the quay for the lads to fight over - and all around were Neapolitans singing their pensive love ballads to the strains of the mandolin and the violin, as our boat cast off and we sailed away. A calm sea and a lovely moonlight passage".

In Palermo: "This is indeed the Orient, strong in colours and great in indolence, but a life of movement such as I have never befor seen... Boys are splashing and bathing in the blue waters, the harbour is filled with masts and gaily-coloured boats with lug sails - and then Castellamare, time-worn, red of hue and with a loggia. The plants clinging to the church walls are in bloom, the sun is burning hot, the light is dazzling white". In Siracusa: "We drank coffee and Strega at a little cafè on the cathedral square in the midst of the crowd and the charming and rather impudent Italian carnival figures. Offered cigarettes to ruffians, played ball with children, let people throw confetti in our mouths, made eyes at darkeyed Sicilian beauties chinking their castanet, gathered quite a crowd around us". In Tunis: "Tunis, this is the most amusing I have come across in the 28 years of my existence! Not as a town of art, but for its outstanding gay and lively character. (Of course, I said something much the same about Palermo, but that has faded away now!)". Asplund's is interested in every sort of open air, daily life expression: the anonymous building; the life in the square; the proportions of a public washtub in Cefalù; the Venetian palace's light reflections and their image mirrored in the canal; Naples's carnival; the main road of small Sicilian towns, the "lampare" taking the sea. In his notes it seems that the coastal inhabitant's movements and customs are able to describe places. The way people live a space is what creates its value. The way they move around gives a measure of it and underlines its human scale. During his Italian journey, Asplund never takes photos without portraying people, showing that architecture doesn't exist without its inhabitants, it doesn't exist without the inhabitants' and observer's 
feelings (Mansilla 2008). Architecture and urban scenes are analysed by understanding social principles and community life.

Figure 10. Groundfloor of the House of the Tragic Poet; Groundfloor of Maison La Roche; Le Corbusier. Sketch of the Groundfloor of the House of the Tragic Poet
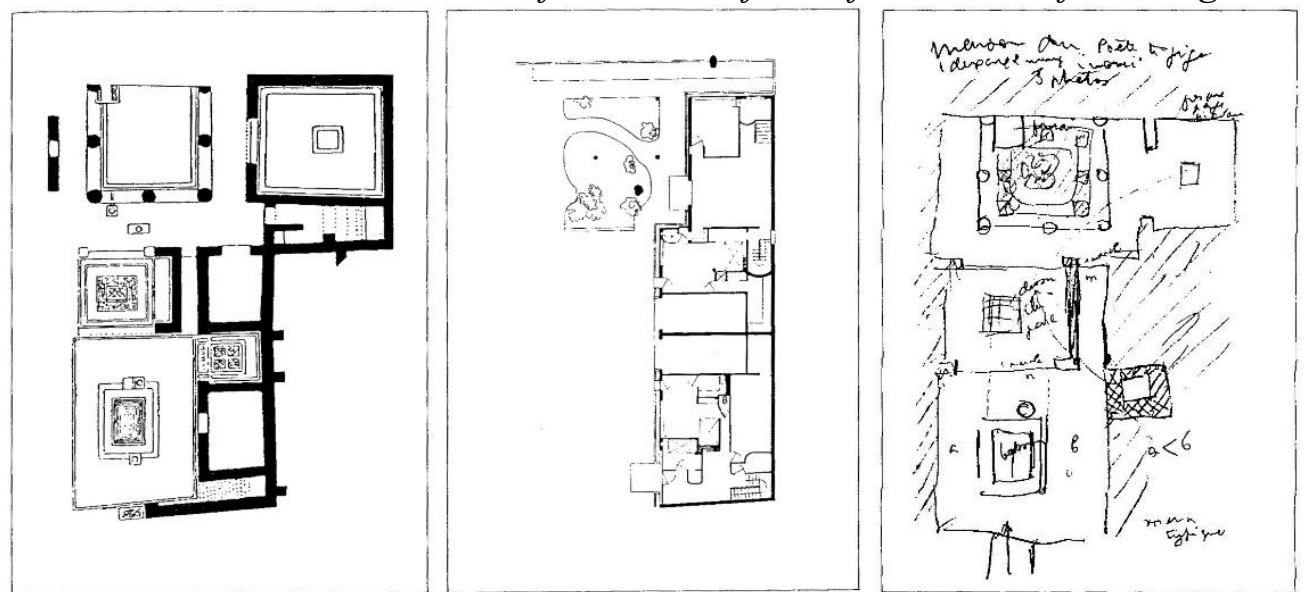

Source: Forster 1979.

Figure 11. Alvar Aalto, Venice, 1924

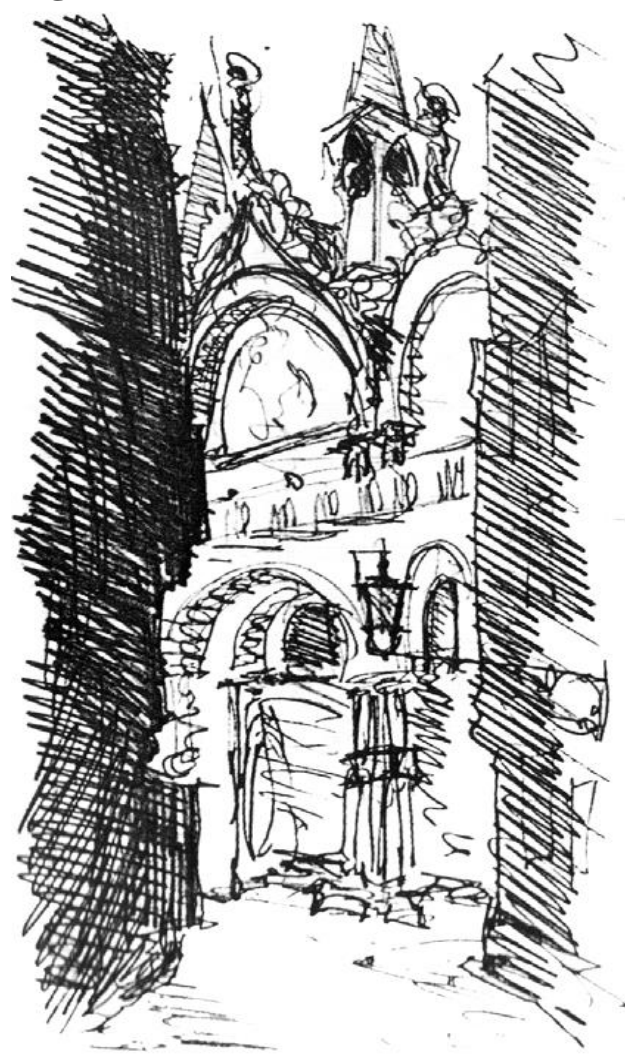

Source: Lotus International, 68, 1991. 
Figure 12. Louis Kahn, Florence, 1950

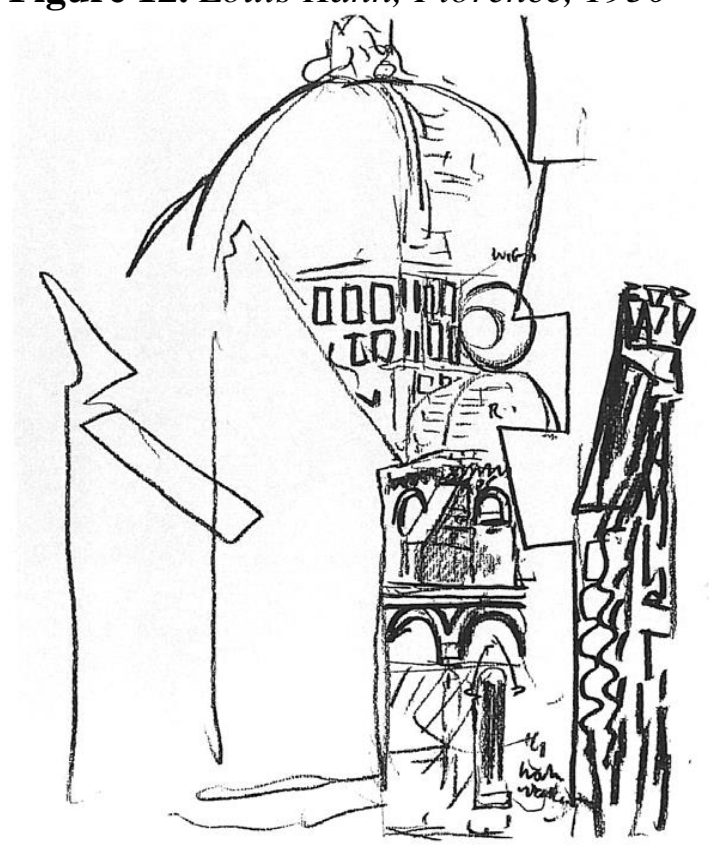

Source: Feldman E., Wurman R.S., The Notebooks And Drawings Of Louis I. Khan, The Falcon Press, Philadelphia, 1962.

Aalto, Kahn, and Alvaro Siza also try to underline these spaces' proportions through their drawings, as if the street narrowness was the main reason for its use; the more it arrived to a greater space, like a square, a "campo", or a widening, the better. Volumes define the rest, together with the way they lay on the ground. Inhabitants and light are the two elements defining the space of the city. Voids become stronger thanks to the dimensional contrast with the urban fabric compression, made of shadows and narrow streets. The relationship between mass and void leads the game and draws big spaces, the position and rotation of volumes give to their negative a better value. The rest is due to light, as if light could not only describe a space, but also define its real proper uses. What happens in urban voids is very important for travellers to understand the unwritten rules of a shifty city, where orthogonal layouts disappear to host ever-changing three-dimensional paths. The key of the rediscovered Mediterranean architecture seems to be in the relationships, in the in-between and in its very measures (Figures 10-11-12).

\section{Conclusions: Crossbreeding in Contemporary Architecture}

The Mediterranean is a complex field that eludes its geographical borders and asserts itself as a cultural landscape through the power of image, from which form and proportions derive. For this reason, the Mediterranean defines a sense of belonging beyond personal data and places of residence; it is based on the perception of landscape and on the capacity of recognizing certain flavours, smells, perfumes, materials, and sounds. 
Many contemporary architects use the topics I have addressed in this paper, a kind of citation aware of the Mediterranean as a landscape translated by human thought. Portuguese architecture discovers the Mediterranean thanks to Aalto, through the figure of Alvaro Siza; traditional topics come back in the basin's contemporary architecture, filtered by strangers and ex-travellers, as for example Barragan, to be later on contaminated and enriched even more. The Mediterranean flows in the veins of contemporary architecture.

\section{References}

VvAa (1991) L'occhio dell'architetto. In "Lotus", 68.

Aalto A (1926) Fragment. In G Schildt (1986). Alvar Aalto: The Decisive Years. New York: Rizzoli.

Asplund G (1913) Notes. In VvAa (1981) Gunnar Asplund Architect 1885-1940: Plans, Sketches and Photographs. Stockholm: Byggforlaget.

Le Corbusier (1965) Fragment. VvAa (1987) Le Corbusier Et La Méditerranée. Marseille: Editions Parenthèses.

Barragan L (1984) Fragment. Ramìrez Ugarte A (1984) Los jardines de Luis Barragan. Mexico en el Arte, 5. Mexico: Nueva Epoca.

Braudel F (1990) La Méditerranée et le monde méditerranée à l'époque de Philippe II. Paris: Armand Colin.

Buccaro A, Mainini G (2006) Luigi Cosenza Oggi 1905/2005. Napoli: Clean Edizioni.

Capitel A (2002) José Luis Sert. Valladolid: Universidad de Valladolid.

Capponi G (1927) Motivi di Architettura Ischiana. Architettura e arti decorative, 11. Milano: Bestetti e Tumminelli.

Cerio E (1922) L'architettura Minima Nella Contrada Delle Sirene. Architettura e Arti Decorative, 4. Milano: Bestetti e Tumminelli.

Egidi P (1921) Appunti su Alcune Costruzioni di Siria e Palestina. Architettura e arti decorative, 5. Milano: Bestetti e Tumminelli.

Feldman E, Wurman RS (1962) The Notebooks and Drawings of Louis I. Kahn. Philadelphia: The Falcon Press.

Ferro L (2004) In Grecia, archeologia architettura paesaggio. Boves: Araba Fenice Edizioni.

Figini L (1950) Architettura Naturale a Ibiza. Comunità, 8. Ivrea: Fondazione Adriano Olivetti.

Forster KW (1979) Antiquity and Modernity in the La Roche-Jeanneret- House of 1923. Opposition, 15/16. San Francisco: The Institute for Architecture and Urban Studies.

Frampton K, Reed P (1998) Alvar Aalto: Between Humanism and Materialism. New York: Museum of Modern Art.

Goethe JW (1816) Italian Journey. Ed. Ingl. (1992). London: Penguin books.

Le Corbusier (1911) Fragment. I Žaknić (1987) Le Corbusier, Journey to the East. London: MIT Press.

Le Corbusier (1928) Toward an Architecture. Ried: Getty publication.

Le Corbusier (1931) Fragment. Plans 8. Paris: Revue Plan.

Lejeune JF, Sabatino M (2010) Modern Architecture and the Mediterranean. Oxon: Routledge.

Maiuri A (1924) Architettura Paesana a Rodi-La Casa di Lindo. Architettura e Arti Decorative, 9. Milano: Bestetti e Tumminelli. 
Mansilla LM (2008) Apuntes de viaje al interior del tiempo. Barcelona: Editorial Gustavo Gili.

Marconi P (1929) Architetture Minime Mediterranee e Architettura Moderna. Architettura ed Arti Decorative, I. Milano: Bestetti e Tumminelli.

Martinez AR (1996) 1902-1988 Luis Barragan. Milano: Electa.

Mendelsohn E (1931) Letter to his wife. Lejeune JF, Sabatino M (2010) Modern Architecture and the Mediterranean. Oxon: Routledge.

Kahn LI (1951) Fragment. McCarter R (2005). Louis I. Kahn. London: Phaidon.

Pagano G (1935) Documenti di Architettura rurale. Casabella, 8, 95. Torino: Arnoldo Mondadori Editore.

Pane R (1928) Tipi di Architettura Rustica in Napoli e Campi Flegrei. Architettura e Arti Decorative, 12. Milano: Bestetti e Tumminelli.

Pollini G (1933) Corsivo n. 40. Quadrante, 5. Milano: Modiano.

Rudofsky B (1938) Non ci vuole un nuovo modo di costruire ci vuole un nuovo modo di vivere. Domus, 16. Rozzano: Editoriale Domus.

Sabatino M (2008) Ghosts and Barbarians: The Vernacular in Italian Modern Architecture and Design. Journal of Design History, 21, 4.

Schildt G (1986) Alvar Aalto: the decisive years. New York: Rizzoli.

Sert L (1935) Fragment. Pizza A (1997) Sert y el Mediterraneo. Barcelona: Col-legi d'arquitectes de Catalunya.

Sert L (1950) Fragment. Pizza A (1997) Sert y el Mediterraneo. Barcelona: Col-legi d'arquitectes de Catalunya.

Weston R (1995) Alvar Aalto. London: Phaidon Press. 
